\title{
Cohnella arctica sp. nov., isolated from Arctic tundra soil
}

\author{
Fan Jiang, Jun Dai, Yang Wang, Xiuqing Xue, Mengbo Xu, Wenxin Li, \\ Chengxiang Fang and Fang Peng
}

Correspondence

Fang Peng

fangpeng2@yahoo.com.cn

\begin{abstract}
China Center for Type Culture Collection (CCTCC), College of Life Sciences, Wuhan University, Wuhan 430072, PR China
\end{abstract}

\begin{abstract}
A psychrotolerant Gram-reaction-negative, rod-shaped and orange-pigmented bacterium, designated strain $\mathrm{M} 9-62^{\top}$, which was motile by means of peritrichous flagella, was isolated from tundra soil sampled near Ny-Ålesund, Svalbard Islands, Norway $\left(78^{\circ} \mathrm{N}\right)$. Growth occurred at 4$30{ }^{\circ} \mathrm{C}$ (optimum, $25^{\circ} \mathrm{C}$ ) and $\mathrm{pH} 5.0-8.0$ (optimum, $\mathrm{pH} 6.0-7.0$ ). Analysis of the 16S rRNA gene sequence of strain M9-62 $2^{\top}$ placed it in the genus Cohnella; sequence similarities of the isolate with type strains of members of related genera ranged from 92.0 to $96.3 \%$. Strain M9-62 ${ }^{\top}$ contained anteiso- $\mathrm{C}_{15: 0}(51.1 \%)$, iso- $\mathrm{C}_{16: 0}(7.5 \%)$ and $\mathrm{C}_{16: 0}(6.1 \%)$ as the major cellular fatty acids and diphosphatidylglycerol, phosphatidylglycerol, phosphatidylethanolamine and lysylphosphatidylglycerol as the main polar lipids. The major respiratory quinone was MK-7 and the DNA G + C content was 50.3 mol\%. On the basis of phenotypic, chemotaxonomic and phylogenetic data, strain M9-62 ${ }^{\top}$ is considered to represent a novel species of the genus Cohnella, for which the name Cohnella arctica sp. nov. is proposed; the type strain is M9-62 ${ }^{\top}$ $\left(=\right.$ CCTCC AB $2010228^{\top}=$ NRRL B $\left.-59459^{\top}\right)$.
\end{abstract}

The genus Cohnella was proposed by Kämpfer et al. (2006) to accommodate Gram-positive, spore-forming, aerobic, rodshaped bacteria containing MK-7 as the main menaquinone. At the time of writing, the genus Cohnella comprised 12 recognized species isolated from various environments such as soil, fresh water, industrial starch production, human blood, a root nodule of Phaseolus coccineus and a volcanic pond, namely Cohnella thermotolerans (Kämpfer et al., 2006), C. hongkongensis (Kämpfer et al., 2006), C. laeviribosi (Cho et al., 2007), C. phaseoli (García-Fraile et al., 2008), C. yongneupensis and C. ginsengisoli (Kim et al., 2010), C. fontinalis (Shiratori et al., 2010), C. luojiensis (Cai et al., 2010), C. damuensis (Luo et al., 2010), C. thailandensis (Khianngam et al., 2010a), and C. xylanilytica and C. terrae (Khianngam et al., 2010b). In this paper, we isolated a psychrotolerant representative of the genus Cohnella from high Arctic tundra soil and report the results of a phenotypic, genetic and phylogenetic examination.

Strain M9-62 ${ }^{\mathrm{T}}$ was isolated from a soil sample collected from a tundra near the settlement $\mathrm{Ny}$-Ålesund $\left(78^{\circ} 55^{\prime} \mathrm{N}\right.$ $11^{\circ} 58^{\prime}$ E), Svalbard Islands, Norway, in July 2009. At the time of sampling, the soil had a salt content of $0.032 \%$, a $\mathrm{pH}$ of 8.0 and a temperature of $8.3{ }^{\circ} \mathrm{C}$ at $5 \mathrm{~cm}$ below the

The GenBank/EMBL/DDBJ accession number for the $16 \mathrm{~S}$ rRNA gene sequence of strain M9-62 ${ }^{\top}$ is HO315787.

Two supplementary figures are available with the online version of this paper. surface. The soil sample was diluted serially with a sterile $0.85 \%(\mathrm{w} / \mathrm{v}) \mathrm{NaCl}$ solution and these dilutions were plated onto $0.3 \times$ marine broth 2216 (MB; Difco) agar plates. Single colonies on these plates were purified by transferring them onto new plates followed by additional incubation for 7 days at $25{ }^{\circ} \mathrm{C}$. The isolate was tentatively identified by using partial 16S rRNA gene sequence analysis and stored as lyophilized cells.

Cell morphology was examined by using phase-contrast microscopy (Olympus BX51) and transmission electron microscopy (Hitachi 8100). Flagellation was determined by using transmission electron microscopy of cells from an exponentially growing culture. For this purpose, cells were negatively stained with $1 \%(\mathrm{w} / \mathrm{v})$ phosphotungstic acid and the grids were examined after being air-dried. Endospores were stained according to the Schaeffer-Fulton method (Smibert \& Krieg, 1994). The Gram-reaction test was performed on cells grown on $0.3 \times \mathrm{MB}$ agar at $25{ }^{\circ} \mathrm{C}$ for 1-14 days by using the classical Gram procedure described by Doetsch (1981). Gliding motility was investigated as described by Bowman (2000). Growth under anaerobic conditions was tested on $0.3 \times \mathrm{MB}$ agar in a GasPak (BBL) jar at $25{ }^{\circ} \mathrm{C}$ for 20 days. Oxidase activity was evaluated using $1 \%(\mathrm{w} / \mathrm{v})$ tetramethyl- $p$-phenylenediamine. Catalase activity was determined by measurement of bubble production after the application of $3 \%(\mathrm{v} / \mathrm{v}) \mathrm{H}_{2} \mathrm{O}_{2}$ solution. Growth at different temperatures $(0,4,8,15,20$, $25,28,30,37$ and $\left.42{ }^{\circ} \mathrm{C}\right)$ and $\mathrm{pH}$ values $(4.0-11.0$ at $1.0 \mathrm{pH}$ 
unit increments) was investigated on $0.3 \times \mathrm{MB}$ agar for up to 1 week. Tolerance to $0.5,1,2,3,4,5$ and $6 \%(\mathrm{w} / \mathrm{v}) \mathrm{NaCl}$ was assessed on $0.3 \times$ R2A agar (Difco) medium. Growth was also evaluated on several bacteriological media: R2A agar (Difco), $0.3 \times \mathrm{R} 2 \mathrm{~A}$ agar (Difco), nutrient agar (NA; Difco), MacConkey agar (Difco), tryptic soy broth (TSB) agar (Difco) and $0.3 \times \mathrm{MB}$ (Difco) agar at $25^{\circ} \mathrm{C}$. Further biochemical characteristics were determined by using API kits (API ZYM, API 20NE and API ID 32GN) according to the manufacturer's instructions (bioMérieux).

Strain $\mathrm{M} 9-62^{\mathrm{T}}$ was aerobic, Gram-reaction-negative, rodshaped $(0.2-0.3 \times 1.3-2.3 \mu \mathrm{m})$ and motile by means of peritrichous flagella (Supplementary Fig. S1, available in IJSEM Online). Oval spores appeared in a subterminal position within the cells after 7 days growth. The isolate was oxidase-positive and showed weak catalase activity. Growth of the strain was observed on $0.3 \times \mathrm{MB}$ agar at temperatures between 4 and $30{ }^{\circ} \mathrm{C}$ (optimum, $25^{\circ} \mathrm{C}$ ) and at $\mathrm{pH}$ 5.0-8.0 (optimum, $\mathrm{pH}$ 6.0-7.0). The strain showed good growth in the presence of $0.5 \%(\mathrm{w} / \mathrm{v}) \mathrm{NaCl}$ in $0.3 \times$ $\mathrm{R} 2 \mathrm{~A}$, but no growth occurred in the presence of $\geqslant 1.0 \%$ $(\mathrm{w} / \mathrm{v}) \mathrm{NaCl}$. Colonies were orange, circular, convex and smooth after growth for 7 days at $25{ }^{\circ} \mathrm{C}$ on $0.3 \times \mathrm{MB}$ agar. The isolate grew well at $25{ }^{\circ} \mathrm{C}$ on R2A agar, $0.3 \times \mathrm{R} 2 \mathrm{~A}$ agar, $\mathrm{NA}$ and $0.3 \times \mathrm{MB}$ agar, but not on MacConkey agar or TSB agar. Other characteristics are summarized in the species description and those that differentiate strain M9$62^{\mathrm{T}}$ from closely related type strains are shown in Table 1.

Genomic DNA was extracted with a Bacteria Genomic DNA Isolation kit (Shanghai Chaoshi Bio Technologies). PCR amplification of the 16S rRNA gene was performed using an established method (Lane, 1991) and PCR products were sequenced by Invitrogen Biotechnology. Sequence similarity was calculated by pairwise alignment obtained from the EzTaxon database (Chun et al., 2007). Sequences were aligned using CLUSTAL_X software (Thompson et al.,

Table 1. Differential characteristics of strain $\mathrm{M} 9-62^{\top}$ and related Cohnella species

Strains: 1, M9-62 $2^{\mathrm{T}} ; 2$, C. luojiensis HY-22R ${ }^{\mathrm{T}} ; 3$, C. thermotolerans CCUG $47242^{\mathrm{T}} ; 4$, C. phaseoli GSPC1 ${ }^{\mathrm{T}} ; 5$, C. hongkongensis $\mathrm{HKU}^{\mathrm{T}}$. Data are from this study unless otherwise indicated. + , Positive; $(+)$, weakly positive; - , negative.

\begin{tabular}{|c|c|c|c|c|c|}
\hline Characteristics & 1 & 2 & 3 & 4 & 5 \\
\hline Temperature range for growth $\left({ }^{\circ} \mathrm{C}\right)$ & $4-30$ & $10-37^{\star}$ & $20-55 \dagger$ & $10-45 \ddagger$ & $25-50 \dagger$ \\
\hline Flagella & + & $+^{*}$ & $-\dagger$ & $+末$ & $-\dagger$ \\
\hline Nitrate reduction & - & - & - & + & - \\
\hline \multicolumn{6}{|l|}{ Enzyme activity (API ZYM): } \\
\hline Alkaline phosphatase & + & + & + & - & + \\
\hline Lipase $(\mathrm{C} 14)$ & + & - & + & - & - \\
\hline Leucine arylamidase & - & + & + & + & + \\
\hline Acid phosphatase & + & - & + & + & + \\
\hline$\alpha$-Glucosidase & + & - & + & + & + \\
\hline$\beta$-Glucosidase & + & - & + & + & + \\
\hline$\alpha$-Fucosidase & - & - & - & + & + \\
\hline \multicolumn{6}{|l|}{ Assimilation (API 20NE/32GN) of: } \\
\hline D-Glucose & - & + & + & + & + \\
\hline L-Arabinose & - & + & + & + & + \\
\hline D-Mannitol & - & + & + & - & + \\
\hline$N$-Acetylglucosamine & - & + & - & + & - \\
\hline Potassium gluconate & - & - & + & - & - \\
\hline L-Rhamnose & - & - & - & - & + \\
\hline D-Ribose & - & + & - & + & - \\
\hline Inositol & - & + & - & - & - \\
\hline Sucrose & - & + & - & + & + \\
\hline Glycogen & - & - & + & + & - \\
\hline Salicin & - & + & - & + & - \\
\hline Melibiose & - & + & - & + & $(+)$ \\
\hline L-Fucose & - & + & - & + & $(+)$ \\
\hline D-Sorbitol & - & - & - & - & $(+)$ \\
\hline DNA G $+\mathrm{C}$ content $(\mathrm{mol} \%)$ & 50.3 & $49.6^{*}$ & $59 \dagger$ & $60.3 \neq$ & $60.9 \dagger$ \\
\hline
\end{tabular}

${ }^{*}$ Data from Cai et al. (2010).

$\dagger$ Data from Kämpfer et al. (2006).

¥Data from García-Fraile et al. (2008). 
1997). Phylogenetic trees were constructed by neighbourjoining (Saitou \& Nei, 1987) and maximum-parsimony (Fitch, 1971) methods. An evolutionary distance matrix for the neighbour-joining method was generated according to Kimura's two-parameter method (Kimura, 1980) and closeneighbour-interchange (search level $=2$, random additions $=100$ ) was applied in the maximum-parsimony analysis. The topology of the neighbour-joining tree was evaluated by using the bootstrap resampling method with 1000 replicates (Felsenstein, 1985). MEGA version 4.0 (Tamura et al., 2007) was used for all analyses.

The 16S rRNA gene sequence of strain M9-62 ${ }^{\mathrm{T}}$ was a continuous stretch of $1441 \mathrm{bp}$. Sequence comparisons with $16 \mathrm{~S}$ rRNA gene sequences from the EzTaxon database revealed that strain $\mathrm{M} 9-62^{\mathrm{T}}$ had highest similarity with $C$. luojiensis $\mathrm{HY}-22 \mathrm{R}^{\mathrm{T}}(96.3 \%)$, followed by C. yongneupensis 5YN10-14 ${ }^{\mathrm{T}}$ (94.7\%), C. phaseoli $\mathrm{GSPCl}^{\mathrm{T}}(94.4 \%)$, C. ginsengisoli GR21-5 ${ }^{\mathrm{T}}(94.0 \%)$, C. hongkongensis $\mathrm{HKU}^{\mathrm{T}}$ (93.4\%), C. thermotolerans CCUG $47242^{\mathrm{T}}(93.1 \%), C$. xylanilytica MX15-2 $2^{\mathrm{T}}$ (92.9\%), C. laeviribosi $\mathrm{RI}-39^{\mathrm{T}}(92.4 \%)$ and C. fontinalis $\mathrm{YT}-1101^{\mathrm{T}}(92.0 \%)$. These values are well below the threshold for demarcating bacterial species (Stackebrandt \& Goebel, 1994). The neighbour-joining tree (Fig. 1) showed that strain M9-62 ${ }^{\mathrm{T}}$ formed a tight phyletic lineage with type strains of members of the genus Cohnella. The overall topology of the maximum-parsimony tree was essentially the same (data not shown).
Cell biomass for the analysis of respiratory quinones and polar lipids was obtained from cultivation on $0.3 \times \mathrm{MB}$ at $25{ }^{\circ} \mathrm{C}$. Respiratory quinones were extracted and identified by HPLC (UltiMate 3000; Dionex) as described by Xie \&Yokota (2003). For cellular fatty acid analysis, strain M9$62^{\mathrm{T}}$ and four reference strains (C. luojiensis $\mathrm{HY}-22 \mathrm{R}^{\mathrm{T}}, C$. thermotolerans CCUG $47242^{\mathrm{T}}$, C. phaseoli GSPC1 ${ }^{\mathrm{T}}$ and $C$. hongkongensis $\mathrm{HKU}^{\mathrm{T}}$ ) were grown on $0.3 \times \mathrm{MB}$ agar plates at $25{ }^{\circ} \mathrm{C}$; cells grown at late-exponential phase were used in this study. Harvesting, saponification, methylation and extraction of cellular fatty acids were carried out according to the protocol of the Sherlock Microbial Identification System (MIDI) version 6.0. Separation and identification of fatty acid methyl esters was performed using a Hewlett Packard 6890N GC, with the MIDI Sherlock TSBA6 database (Sasser, 1990). The DNA G $+C$ content of strain M9-62 ${ }^{\mathrm{T}}$ was determined by HPLC according to the method of Mesbah et al. (1989). Polar lipids were extracted and analysed by two-dimensional TLC (silica gel plates, layer thickness $0.2 \mathrm{~mm}$; Merck) according to Tindall (1990).

Strain M9-62 ${ }^{\mathrm{T}}$ contained MK-7 as the predominant respiratory quinone. The major cellular fatty acids of strain M9-62 ${ }^{\mathrm{T}}$ were anteiso- $\mathrm{C}_{15: 0}(51.1 \%)$, iso- $\mathrm{C}_{16: 0}(7.5 \%)$ and $\mathrm{C}_{16: 0}(6.1 \%)$, which were consistent with data for recognized Cohnella species. However, differences in the fatty acid contents of strain M9-62 ${ }^{\mathrm{T}}$ and closely related type strains of members of the genus Cohnella demonstrate

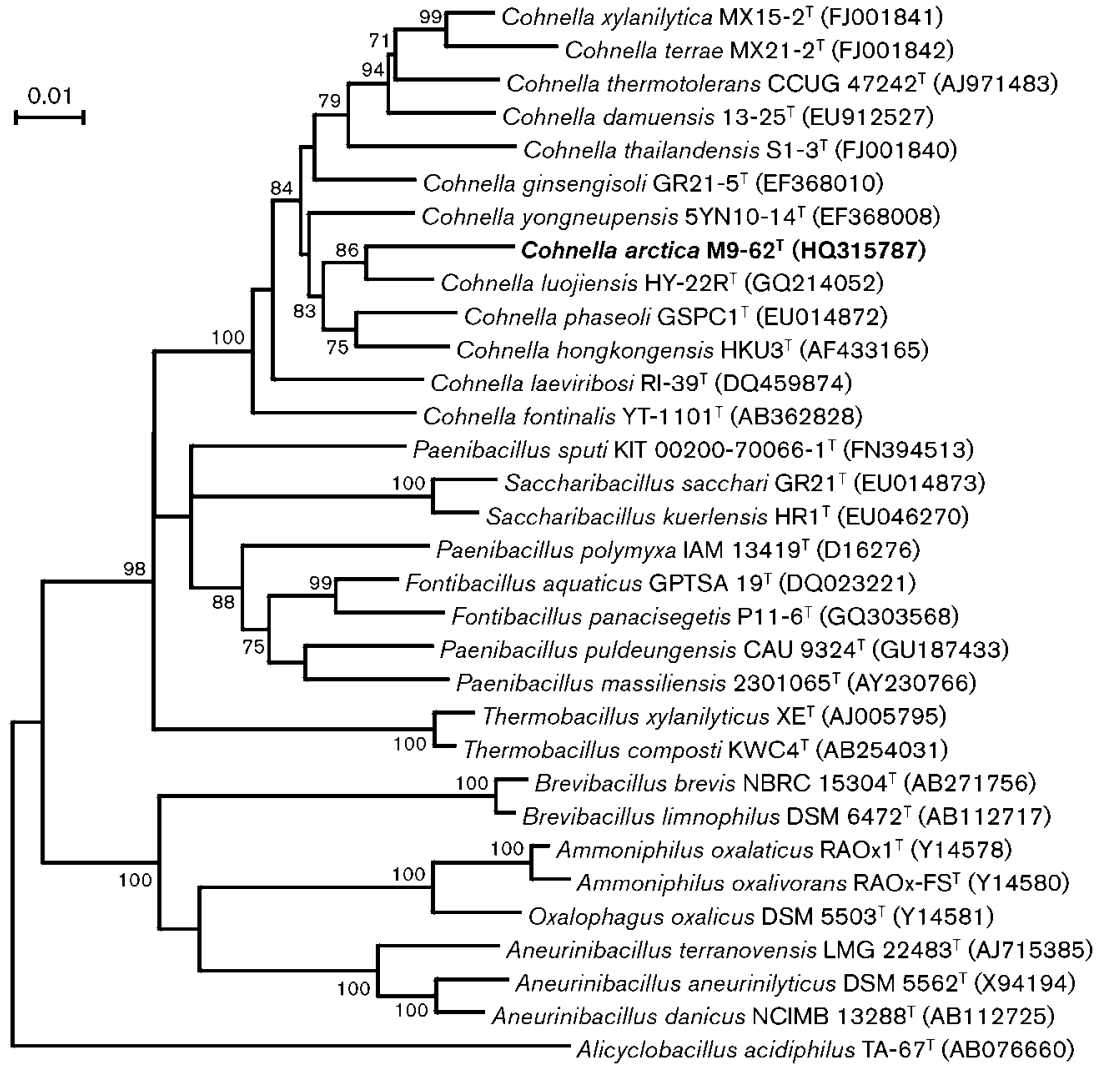

Fig. 1. Neighbour-joining phylogenetic tree, based on 16S rRNA gene sequences, showing the relationship between strain M9-62 ${ }^{\top}$ and related taxa. Bootstrap values (\%; 1000 replications) greater than $70 \%$ are shown at nodes. The sequence of Alicyclobacillus acidiphilus TA $-67^{\top}$ was used as an outgroup. Bar, 0.01 substitutions per nucleotide position. 
Table 2. Cellular fatty acid compositions (\%) of strain M9-62 ${ }^{\top}$ and closely related strains

Strains: $1, \mathrm{M} 9-62^{\mathrm{T}}$; 2, C. luojiensis $\mathrm{HY}-22 \mathrm{R}^{\mathrm{T}} ; 3$, C. thermotolerans CCUG $47242^{\mathrm{T}}$; 4, C. phaseoli GSPC1 ${ }^{\mathrm{T}}$; 5 , C. hongkongensis $\mathrm{HKU}^{\mathrm{T}}$. Data were obtained in this study. - , Not detected or $<1 \%$.

\begin{tabular}{|c|c|c|c|c|c|}
\hline Fatty acid & 1 & 2 & 3 & 4 & 5 \\
\hline anteiso- $\mathrm{C}_{13: 0}$ & 2.5 & 2.7 & - & 2.1 & 3.7 \\
\hline $\mathrm{C}_{13: 0}$ & 1.5 & - & - & - & 2.0 \\
\hline $\mathrm{C}_{14: 0}$ & 2.8 & 2.3 & 3.1 & 3.1 & 7.0 \\
\hline iso- $\mathrm{C}_{14: 0}$ & 5.9 & 3.8 & 3.4 & 4.0 & 7.7 \\
\hline iso- $\mathrm{C}_{13: 0} 3-\mathrm{OH}$ & - & - & - & - & 1.3 \\
\hline iso- $\mathrm{C}_{15: 1}-\mathrm{F}$ & - & - & - & - & 1.3 \\
\hline anteiso- $\mathrm{C}_{15: 0}$ & 51.1 & 53.3 & 26.8 & 38.6 & 31.5 \\
\hline iso- $\mathrm{C}_{15: 0}$ & 1.8 & 5.0 & 1.0 & 2.3 & 1.5 \\
\hline $\mathrm{C}_{16: 0}$ & 6.1 & 9.4 & 14.0 & 14.9 & 15.3 \\
\hline iso- $\mathrm{C}_{16: 0}$ & 7.5 & 12.8 & 26.3 & 15.0 & 8.9 \\
\hline $\mathrm{C}_{16: 1} \omega 11 c$ & 4.2 & 1.2 & 1.8 & 3.1 & 1.9 \\
\hline $\mathrm{C}_{16: 1} \omega 7 c$ alcohol & 6.6 & 1.9 & 1.7 & 4.0 & 2.6 \\
\hline anteiso- $\mathrm{C}_{17: 0}$ & 1.5 & 2.5 & 3.7 & 3.2 & 1.5 \\
\hline $\mathrm{C}_{17: 0}$ & 1.6 & - & - & 3.7 & 1.2 \\
\hline $\mathrm{C}_{18: 1} \omega 9 c$ & - & - & 1.8 & - & 2.5 \\
\hline $\mathrm{C}_{18: 0}$ & - & - & 8.0 & - & 4.7 \\
\hline \multicolumn{6}{|l|}{ Summed features ${ }^{\star}$} \\
\hline 1 & - & - & - & - & 1.1 \\
\hline 8 & - & - & 4.0 & - & 1.1 \\
\hline
\end{tabular}

${ }^{*}$ Summed feature 1 contains iso- $\mathrm{C}_{15: 1} \mathrm{H}$ and/or $\mathrm{C}_{13: 0}$ 3-OH; summed feature 8 contains $\mathrm{C}_{18: 1} \omega 7 c$ and/or $\mathrm{C}_{18: 1} \omega 6 c$.

that strain M9-62 ${ }^{\mathrm{T}}$ is not a member of known Cohnella species (Table 2). The DNA G $+\mathrm{C}$ content of the novel isolate was $50.3 \mathrm{~mol} \%$, which is consistent with the range reported for the genus Cohnella (49.6-65.1 mol\%; Kämpfer et al., 2006; Cai et al., 2010; Khianngam et al., 2010a). The major polar lipids of strain $\mathrm{M} 9-62^{\mathrm{T}}$ were diphosphatidylglycerol, phosphatidylglycerol, phosphatidylethanolamine and lysyl-phosphatidylglycerol (Supplementary Fig. S2, available in IJSEM Online); these polar lipids are characteristic of members of the genus Cohnella (Kämpfer et al., 2006). Five unknown phospholipids (PL1 to 5) and three unknown aminophospholipids (PN1, PN3 and PN4) were also detected.

On the basis of the data presented, strain M9- $62^{\mathrm{T}}$ is considered to represent a novel species of the genus Cohnella, for which the name Cohnella arctica sp. nov. is proposed.

\section{Description of Cohnella arctica sp. nov.}

Cohnella arctica (arc'ti.ca. L. fem. adj. arctica northern, from the Arctic, referring to the site where the type strain was isolated).

Cells are aerobic, Gram-reaction-negative, rod-shaped $(0.2-0.3 \times 1.3-2.3 \mu \mathrm{m})$ and motile by means of peritrichous flagella. Oval subterminal spores are formed. Growth occurs on R2A agar, $0.3 \times \mathrm{R} 2 \mathrm{~A}$ agar, NA and $0.3 \times \mathrm{MB}$ agar, but not on MacConkey agar or TSB agar. Colonies grown on $0.3 \times \mathrm{MB}$ agar are orange, circular, convex and smooth. Growth occurs between 4 and $30{ }^{\circ} \mathrm{C}$ with optimum growth at $25^{\circ} \mathrm{C}$. The $\mathrm{pH}$ range for growth is $\mathrm{pH}$ 5.0-8.0, with optimum growth at $\mathrm{pH}$ 6.0-7.0. Growth occurs in the presence of $0.5 \%(\mathrm{w} / \mathrm{v}) \mathrm{NaCl}$, but no growth occurs in the presence of $\geqslant 1.0 \%(\mathrm{w} / \mathrm{v}) \mathrm{NaCl}$. Oxidasepositive and shows weak catalase activity. In the API ZYM gallery, alkaline phosphatase, esterase (C4), esterase lipase (C8), lipase (C14), acid phosphatase, naphthol-AS-BIphosphohydrolase, $\alpha$-galactosidase, $\beta$-galactosidase, $\alpha$-glucosidase and $\beta$-glucosidase activities are present, but leucine arylamidase, valine arylamidase, cystine arylamidase, trypsin, $\alpha$-chymotrypsin, $\beta$-glucuronidase, $N$-acetyl- $\beta$-glucosaminidase, $\alpha$-mannosidase and $\alpha$-fucosidase activities are absent. In API 20NE, positive for aesculin hydrolysis and $\beta$ galactosidase activity, and negative for nitrate reduction, indole production, glucose fermentation, arginine dihydrolase, and urea and gelatin hydrolysis. In API 20NE and API ID $32 \mathrm{GN}$ strips, assimilates D-mannose and maltose; does not assimilate D-glucose, L-arabinose, D-mannitol, $\mathrm{N}$ acetylglucosamine, potassium gluconate, capric acid, adipic acid, malic acid, trisodium citrate, phenylacetic acid, Lrhamnose, D-ribose, inositol, sucrose, itaconic acid, suberic acid, sodium malonate, sodium acetate, lactic acid, L-alanine, potassium 5-ketogluconate, glycogen, 3-hydroxybenzoic acid, L-serine, salicin, melibiose, L-fucose, Dsorbitol, propionic acid, valeric acid, L-histidine, potassium 2-ketogluconate, 3-hydroxybutyric acid, 4-hydroxybenzoic acid or L-proline. MK-7 is the predominant respiratory quinone. The major cellular fatty acids are anteiso- $\mathrm{C}_{15: 0}$, iso$\mathrm{C}_{16: 0}$ and $\mathrm{C}_{16: 0}$. Major polar lipids are diphosphatidylglycerol, phosphatidylglycerol, phosphatidylethanolamine and lysyl-phosphatidylglycerol.

The type strain, M9-62 ${ }^{\mathrm{T}}\left(=\mathrm{CCTCC}\right.$ AB $2010228^{\mathrm{T}}=\mathrm{NRRL}$ $\mathrm{B}-59459^{\mathrm{T}}$ ), was isolated from a tundra soil near Ny-Ålesund, Svalbard Islands, Norway. The DNA G $+\mathrm{C}$ content of the type strain is $50.3 \mathrm{~mol} \%$.

\section{Acknowledgements}

This work was supported by the National Basic Research Program of China (973 Program) (2011CB808800), the R \& D Infrastructure and Facility Development Program from the Ministry of Science and Technology of the People's Republic of China (grant no. 2005DKA21208) and the State Oceanic Administration, PR China (project no. 10/11YR06).

\section{References}

Bowman, J. P. (2000). Description of Cellulophaga algicola sp. nov., isolated from the surfaces of Antarctic algae, and reclassification of Cytophaga uliginosa (ZoBell and Upham 1944) Reichenbach 1989 as Cellulophaga uliginosa comb. nov. Int J Syst Evol Microbiol 50, 1861-1868.

Cai, F., Wang, Y., Qi, H., Dai, J., Yu, B., An, H., Rahman, E. \& Fang, C. (2010). Cohnella luojiensis sp. nov., isolated from soil of a Euphrates poplar forest. Int J Syst Evol Microbiol 60, 1605-1608. 
Cho, E. A., Lee, J. S., Lee, K. C., Jung, H. C., Pan, J. G. \& Pyun, Y. R. (2007). Cohnella laeviribosi sp. nov., isolated from a volcanic pond. Int J Syst Evol Microbiol 57, 2902-2907.

Chun, J., Lee, J.-H., Jung, Y., Kim, M., Kim, S., Kim, B. K. \& Lim, Y. W. (2007). EzTaxon: a web-based tool for the identification of prokaryotes based on $16 \mathrm{~S}$ ribosomal RNA gene sequences. Int J Syst Evol Microbiol 57, 2259-2261.

Doetsch, R. N. (1981). Determinative methods of light microscopy. In Manual of Methods for General Bacteriology, pp. 21-33. Edited by P. Gerhardt, R. G. E. Murray, R. N. Costilow, E. W. Nester, W. A. Wood, N. R. Krieg \& G. H. Phillips. Washington, DC: American Society for Microbiology.

Felsenstein, J. (1985). Confidence limits on phylogenies: an approach using the bootstrap. Evolution 39, 783-791.

Fitch, W. M. (1971). Toward defining the course of evolution: minimum change for a specific tree topology. Syst Zool 20, 406-416.

García-Fraile, P., Velázquez, E., Mateos, P. F., Martínez-Molina, E. \& Rivas, R. (2008). Cohnella phaseoli sp. nov., isolated from root nodules of Phaseolus coccineus in Spain, and emended description of the genus Cohnella. Int J Syst Evol Microbiol 58, 1855-1859.

Kämpfer, P., Rosselló-Mora, R., Falsen, E., Busse, H.-J. \& Tindall, B. J. (2006). Cohnella thermotolerans gen. nov., sp. nov., and classification of 'Paenibacillus hongkongensis' as Cohnella hongkongensis sp. nov. Int J Syst Evol Microbiol 56, 781-786.

Khianngam, S., Tanasupawat, S., Akaracharanya, A., Kim, K. K., Lee, K. C. \& Lee, J.-S. (2010a). Cohnella thailandensis sp. nov., a xylanolytic bacterium from Thai soil. Int J Syst Evol Microbiol 60, 2284-2287.

Khianngam, S., Tanasupawat, S., Akaracharanya, A., Kim, K. K., Lee, K. C. \& Lee, J.-S. (2010b). Cohnella xylanilytica sp. nov. and Cohnella terrae sp. nov., xylanolytic bacteria from soil. Int J Syst Evol Microbiol 60, 2913-2917.

Kim, S. J., Weon, H. Y., Kim, Y. S., Anandham, R., Jeon, Y. A., Hong, S. B. \& Kwon, S. W. (2010). Cohnella yongneupensis sp. nov. and Cohnella ginsengisoli sp. nov., isolated from two different soils. Int $J$ Syst Evol Microbiol 60, 526-530.

Kimura, M. (1980). A simple method for estimating evolutionary rates of base substitutions through comparative studies of nucleotide sequences. J Mol Evol 16, 111-120.
Lane, D. J. (1991). 16S/23S rRNA sequencing. In Nucleic Acid Techniques in Bacterial Systematics, pp. 115-175. Edited by E. Stackebrandt \& M. Goodfellow. Chichester: Wiley.

Luo, X., Wang, Z., Dai, J., Zhang, L. \& Fang, C. (2010). Cohnella damensis sp. nov., a motile xylanolytic bacteria isolated from a low altitude area in Tibet. J Microbiol Biotechnol 20, 410-414.

Mesbah, M., Premachandran, U. \& Whitman, W. B. (1989). Precise measurement of the $\mathrm{G}+\mathrm{C}$ content of deoxyribonucleic acid by highperformance liquid chromatography. Int J Syst Bacteriol 39, 159167.

Saitou, N. \& Nei, M. (1987). The neighbor-joining method: a new method for reconstructing phylogenetic trees. Mol Biol Evol 4, 406425.

Sasser, M. (1990). Identification of bacteria by gas chromatography of cellular fatty acids, MIDI Technical Note 101. Newark, DE: MIDI Inc.

Shiratori, H., Tagami, Y., Beppu, T. \& Ueda, K. (2010). Cohnella fontinalis sp. nov., a xylanolytic bacterium isolated from fresh water. Int J Syst Evol Microbiol 60, 1344-1348.

Smibert, R. M. \& Krieg, N. R. (1994). Phenotypic characterization. In Methods for General and Molecular Bacteriology, pp. 607-654. Edited by P. Gerhardt, R. G. E. Murray, W. A. Wood \& N. R. Krieg. Washington, DC: American Society for Microbiology.

Stackebrandt, E. \& Goebel, B. M. (1994). Taxonomic note: a place for DNA-DNA reassociation and 16S rRNA sequence analysis in the present species definition in bacteriology. Int J Syst Bacteriol 44, 846849.

Tamura, K., Dudley, J., Nei, M. \& Kumar, S. (2007). MEGA4: molecular evolutionary genetics analysis (MEGA) software version 4.0. Mol Biol Evol 24, 1596-1599.

Thompson, J. D., Gibson, T. J., Plewniak, F., Jeanmougin, F. \& Higgins, D. G. (1997). The CLUSTAL_X windows interface: flexible strategies for multiple sequence alignment aided by quality analysis tools. Nucleic Acids Res 25, 4876-4882.

Tindall, B. J. (1990). Lipid composition of Halobacterium lacusprofundi. FEMS Microbiol Lett 66, 199-202.

Xie, C. H. \& Yokota, A. (2003). Phylogenetic analyses of Lampropedia hyalina based on the 16S rRNA gene sequence. J Gen Appl Microbiol 49, 345-349. 